\title{
DRY OLIVE POMACE GASIFICATION TO OBTAIN ELECTRICAL ENERGY IN A DOWNDRAFT GASIFIER
}

\author{
MARÍA DE LA TORRE MAROTO ${ }^{1,2}$, JOSÉ ANTONIO LA CAL HERRERA ${ }^{2,3}$ \& MANUEL MOYA VILAR ${ }^{1}$ \\ ${ }^{1}$ Department of Chemical and Environmental Engineering (TEP 233), \\ Center for Advanced Studies in Energy and Environment (CEAEMA), University of Jaén, Spain \\ ${ }^{2}$ Recursos Estratégicos de Biomasa, S.L., Spain \\ ${ }^{3}$ Department of Business Organization, University of Jaén, Spain
}

\begin{abstract}
Olive pomace is the main by-product generated by the olive oil mills, representing $80 \%$ of total fruit weight, which has high water content $(60-70 \%)$. Reducing its moisture to $10-15 \%$, the dry olive pomace (DOP) is obtained, which is a very interesting biofuel with a high calorific value $(\sim 4,100 \mathrm{kcal} / \mathrm{kg})$. Annually, large quantities of this product are produced, nevertheless only part of it is used for self-consumption through electrical and thermal energy generation, by combustion. Olive oil mills are industries with high electrical energy consumption. The present study aims to give added value to this material, in order to supply electrical energy to the industries for self-consumption. The pelletized DOP (PDOP) has been subject to a gasification process using a downdraft fixed-bed gasifier in a pilot plant. The gas produced - syngas - has been cleaned through different filtering stages. Subsequently, it is introduced into a genset in order to generate electrical and thermal energy. The generated syngas has very promising characteristics, such as an upper calorific value (HHV) of $1,337.11 \mathrm{kcal} / \mathrm{Nm}^{3}$ and a high content of nitrogen $\left(\mathrm{N}_{2}\right)$ and hydrogen $\left(\mathrm{H}_{2}\right), 47.29 \%$ and $19.54 \%$, respectively. With this syngas, an average instantaneous power of $10 \mathrm{~kW}$ has been generated for 6 hours. The outcomes show the potential of using DOP as raw materials in the gasification process on an industrial scale. This allows to valorize the generated DOP in the olive oil mills and it contributes to reduce $\mathrm{CO}_{2}$, it is favored the transition to the circular economy in the olive sector.

Keywords: dry olive pomace, biomass gasification, downdraft gasifier, syngas, power generation, selfconsumption, circular economy.
\end{abstract}

\section{INTRODUCTION}

Andalusia is the main olive oil producer region worldwide. The olive grove area in Andalusia amounts to 1.5 million ha [1], which produces around 4.7 million tons of olives (Olea Europaea fruit) per year [2]. This olive is processed in the oil mills to make olive oil. The important activity developed by this sector results in the generation of a large number of byproducts. Given the seasonality of the olive oil processing sector, the generation of this subproduct occurs in a very short time [1], between 4 and 5 months. Managing these agroindustrial by-products has become a problem for the mills, so their recovery is necessary.

Until the end of the 1980 s, the olive oil production process was characterized by a threephase centrifugation system, in which oil, water or "alpechín" and wet olive pomace (WOP) were produced. However, at the beginning of the 1990s, the three-phase process was changed to the two-phase process, in which, in addition to olive oil, a new phase is obtained, a combination of the other two that come out in the three-phase process. Therefore, the olive pomace, or "alperujo", produced contains all the water that previously came out as "alpechín" [3], [4]. Starting from a ton of olive, with $20 \%$ fat richness, $200 \mathrm{~kg}$ of olive oil and $800 \mathrm{~kg}$ of "alperujo" are produced, without adding water to the process. The "alperujo" has a high humidity $(60-70 \%)$, which is why it is necessary to dry it to moisture between $10 \%$ and $15 \%$, obtaining the dry olive pomace (DOP).

DOP has huge potential as a fuel; it is a homogeneous product with a high carbon content, high calorific value and low moisture. Annually, in Andalusia, an amount that ranges between 
1.2 and 1.45 million tons is generated [5]. A part of this production, approximately $20 \%$, is invested in generating the thermal energy necessary for self-consumption by the industries themselves; another part, around $45 \%$, is used as raw material to generate electrical energy in combustion plants; and the rest presents market difficulties at this time, being able to be valued through other alternatives [5]. The industries producing DOP, extractors of olive pomace oil, have a high demand for electrical energy and thermal energy, necessary for drying WOP.

Gasification is a thermochemical process that converts carbonaceous solid materials, such as biomass, into value-added gaseous products (syngas) [6]-[8]. In order for gasification to take place, a process initiating and maintaining agent is required. For this, steam and air are used, or this can be substituted by pure oxygen. In a typical gasification process the following stages take place: drying, pyrolysis, partial combustion and gasification [7], [8].

The different types of gasification processes are classified according to the type of reactor used, namely fluidized bed gasifiers and fixed bed gasifiers. After analyzing the different reactors, it was decided that the one that best suits the industries in the olive grove is the downdraft fixed-bed gasifier, since it is used for smaller units with powers equal to or less than $1 \mathrm{MW}$ [9]. In these gasifiers, the gasifying agent is inserted above the reduction zone, flowing downwards and producing gasification in the lower part of the reactor and, therefore, the output of the gas produced through an ash bed at high temperatures [10]-[12]. These reactors produce less $\operatorname{tar}\left(0.015-3 \mathrm{~g} / \mathrm{Nm}^{3}\right)$ than the rest, because the resulting gas is in optimal conditions for cracking to occur when passing through the hot ash bed [10], [11].

In this paper, a Downdraft fixed-bed gasifier is used. In this reactor the raw material is introduced through the upper part, while the gasifying agent enters through the lower part, at a certain height. The syngas produced flow down with the biomass exiting the bottom of the gasifier [10], as shown in Fig. 1.

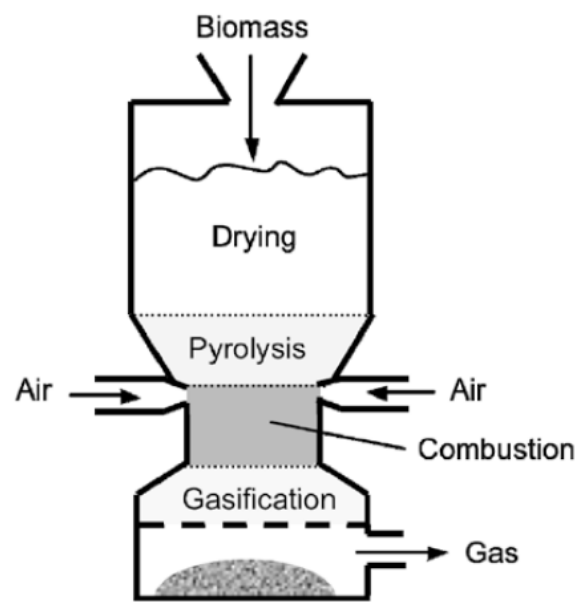

Figure 1: Schematic of a throated-type downdraft gasifier [9].

The aim of this work is the valorization of DOP, through its gasification in a downdraft gasifier. For this, previously, the olive pomace must be densified, due to its high content in fines $(80 \%)$, through the use of a pelletizer, and then it is introduced into the gasifier. Everything will be done at the pilot plant level. 


\section{MATERIALS AND METHODS}

\subsection{Materials characterization}

The wet olive pomace comes from an olive industry located in the province of Jaén, Spain. This olive pomace is dried in a rotary dryer, obtaining the raw material object of this study, DOP (Fig. 2(a)). The main physico-chemical characteristics of the product are shown in Table 1. DOP is a good fuel, due to its high calorific value $(4,192 \mathrm{kcal} / \mathrm{kg})$ and its high fixed carbon content $(17.56 \%)$. However, about $80 \%$ of the sample has a particle size of less than $3 \mathrm{~mm}$, therefore, this high content of fines can prevent fluidization during the gasification process.

To improve the biomass fluidization inside the gasifier, DOP is densified in a pelletizer, obtaining pelletized DOP (PDOP) (Fig. 2(b)) $10 \mathrm{~mm}$ in diameter and between $10 \mathrm{~mm}$ and $30 \mathrm{~mm}$ in length.

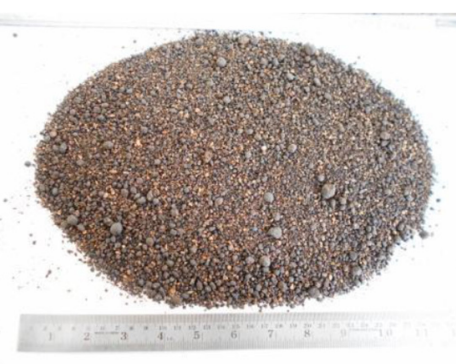

(a)

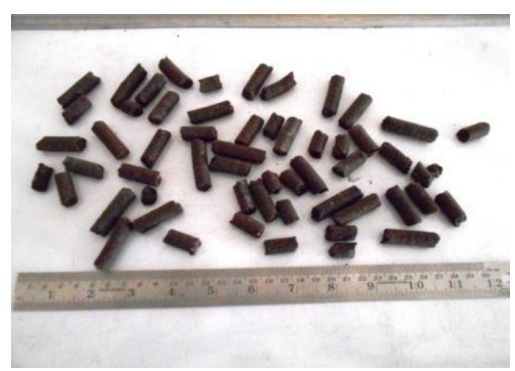

(b)

Figure 2: (a) Sample of dry olive pomace; and (b) Pelletized dry olive pomace.

Table 1: Physico-chemical analyse of dry olive pomace and pelletized dry olive pomace.

\begin{tabular}{|l|c|c|}
\hline Parameters & Dry olive pomace & $\begin{array}{c}\text { Pelletized dry } \\
\text { olive pomace }\end{array}$ \\
\hline Moisture content, $\% \mathrm{wb}$ & 7.07 & 11.63 \\
\hline Ash, $\% \mathrm{db}$ & 9.38 & 7.36 \\
\hline Volatile, $\% \mathrm{db}$ & 73.06 & 71.77 \\
\hline Fixed carbon, $\% \mathrm{db}$ & 17.56 & 20.87 \\
\hline Ash fusion, in ${ }^{\circ} \mathrm{C}$ & - & at 1,200 \\
\hline Ash deformation, in ${ }^{\circ} \mathrm{C}$ & at 1,100 & at 1,100 \\
\hline No Ash fusion, $\mathrm{in}^{\circ} \mathrm{C}$ & at 1,000 & at 1,000 \\
\hline Bulk density, $\mathrm{kg} / \mathrm{m}^{3}$ & 580 & 680 \\
\hline True density, $\mathrm{kg} / \mathrm{m}^{3}$ & - & 1,393 \\
\hline Size, in mm & $>3 \mathrm{~mm}: 20.48 \%$ & Diameter: 10 \\
\hline Ignition test & $<3$ mm: $79.52 \%$ & Length: $10-35$ \\
\hline Flow ability test & Burns easily & Burns easily \\
\hline Calorific value $(\mathrm{HHV}), \mathrm{kcal} / \mathrm{kg} \mathrm{db}$ & Flows easily & Flows easily \\
\hline
\end{tabular}


PDOP has better fuel characteristics than raw DOP and, in addition, allow an increase in the efficiency of the gasification process, while reducing gas treatment costs. The characterization of the PDOP can be seen in Table 1 . When densifying, their calorific value and fixed carbon content are increased, reaching values of $4,429 \mathrm{kcal} / \mathrm{kg}$ and $20.87 \%$ respectively. Furthermore, its ash and volatile compounds content is reduced, going from $9.38 \%$ to $7.36 \%$ in the ash case and from $73.06 \%$ to $71.77 \%$ in the volatiles case.

For these reasons, it was decided to use the PDOP as raw material for the gasification process described below. For this, 5 tons of PDOP were prepared to send to India, where the pilot plant is located where the test will be carried out.

\subsection{Experimental process}

PDOP gasification plant consists of the downdraft fixed-bed gasifier, a gas cooling and cleaning stage, and an engine genset, all at the pilot plant level. An operation scheme is shown in Fig. 3.

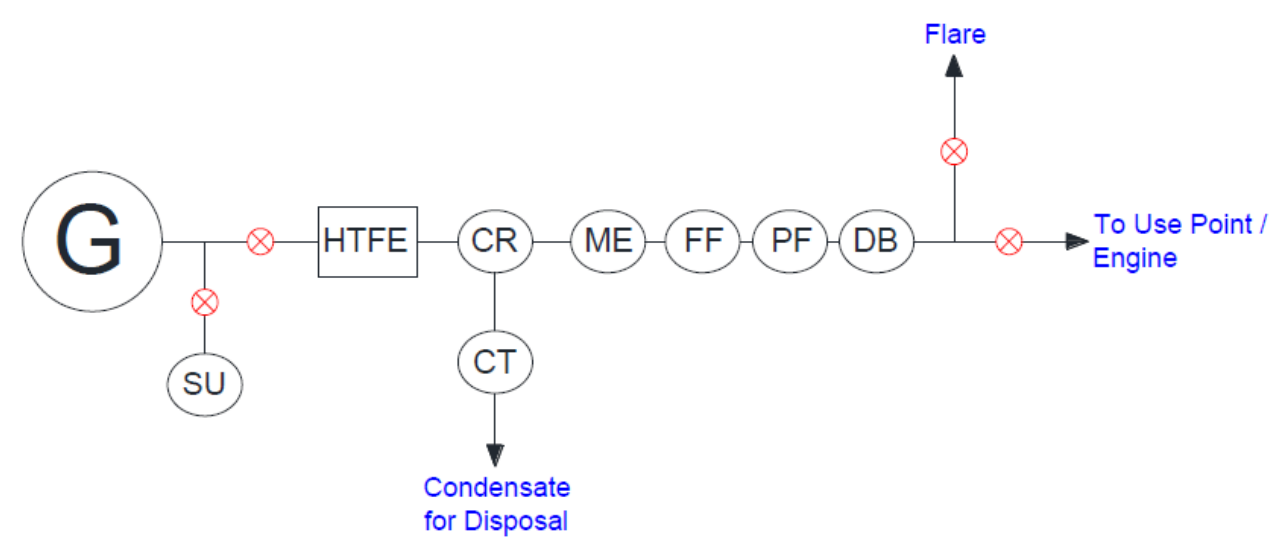

Figure 3: Gasifier schematic system.

The main stage of the process is the Downdraft fixed bed biomass gasifier "Ankur model FBG-100". The components of the gasifier, combustion cone, rotor, vertical grate, inner shell, nozzles, water flow channels and ash pipe are made of special stainless steel alloys, adapted to the conditions that must be met put up with. Some parts, such as hopper, structural support cones, etc., are made of mild steel with the necessary thicknesses and worked and painted appropriately. The entire blower construction is stainless steel.

After the gasifier, the ash removal system and the gas cleaning, dust, tar and inorganic impurities system is installed. This system is made up of high temperature filtering equipment (HTFE), condensate removal subsystem (CR), condensate neutralization subsystem (CT), mist eliminator (ME), fine filter (FF), pleated filter (PF) and, finally, dry blower (DB). The cyclone and scrubber system are also made of suitable stainless steel alloys. Filters are made of mild steel.

After the syngas have been cleaned, there is the engine genset, made up of two $100 \%$ gas engines, to produce electrical energy with a nominal power of $10 \mathrm{kWe}$ and also thermal energy from cooling and exhaust gases. 


\section{RESULTS AND DISCUSSION}

During the test implementation, the Downdraft gasifier was kept running for 9 hours. As a gasifying agent, air at atmospheric pressure was used. The biomass feed to the gasifier has been set at $75 \mathrm{~kg} / \mathrm{h}$. The temperature inside the gasifier ranged from $1,050-1,100^{\circ} \mathrm{C}$. Conditions described above summarize in Table 2.

Table 2: Gasifier operating conditions.

\begin{tabular}{|l|c|}
\hline Parameters & FBG 100 \\
\hline Total run hours & 9 \\
\hline Gasifying agent & Air \\
\hline Pressure & Atmospheric \\
\hline Biomass consumption & $75 \mathrm{~kg} / \mathrm{h}$ \\
\hline Temperature & $1,050-1,100^{\circ} \mathrm{C}$ \\
\hline
\end{tabular}

\subsection{Syngas production}

The syngas characteristics at the gasifier outlet are measured, determining an average syngas flow of $156 \mathrm{Nm}^{3} / \mathrm{h}$ at a variable temperature between $300^{\circ} \mathrm{C}$ and $500^{\circ} \mathrm{C}$. The yield of the determined process has been $71 \%$, in cold gas.

During the test, two gas samples are taken, at different times, to check the possible variation of its characteristics. The gas is collected filtered and clean. Table 3 shows the composition of both samples of the synthesis gas obtained from PDOP. It is observed that both gas samples have a very similar elemental composition with very small variations in the proportion (between $0 \%$ and $3 \%$ ). The calorific value is also very similar in both samples, obtaining an average calorific value of $1,337.11 \mathrm{kcal} / \mathrm{Nm}^{3}$.

Table 3: Produces syngas sampling, analysis and test results.

\begin{tabular}{|l|c|c|c|}
\hline Gas parameters & Unit & Sample 1 & Sample 2 \\
\hline Outlet gas temperature range & ${ }^{\circ} \mathrm{C}$ & \multicolumn{2}{|c|}{$300-500$} \\
\hline Average gas flow & $\mathrm{Nm}^{3} / \mathrm{h}$ & \multicolumn{2}{|c|}{156} \\
\hline Cold gas efficiency of the system & $\%$ & \multicolumn{2}{|c|}{71} \\
\hline $\mathrm{H}_{2}$ & $\%$ & 19.28 & 19.81 \\
\hline $\mathrm{O}_{2}$ & $\%$ & 0.0 & 0.0 \\
\hline $\mathrm{N}_{2}$ & $\%$ & 45.91 & 48.67 \\
\hline $\mathrm{CH}_{4}$ & $\%$ & 2.74 & 2.42 \\
\hline $\mathrm{CO}$ & $\%$ & 15.09 & 15.59 \\
\hline $\mathrm{CO}$ & $\%$ & 16.98 & 13.51 \\
\hline $\mathrm{Calorific}$ value $(\mathrm{HHV})$ & $\mathrm{\% cal} / \mathrm{Nm}^{3}$ & $1,336.11$ & $1,338.12$ \\
\hline Average HHV & $\mathrm{kcal} / \mathrm{Nm}^{3}$ & \multicolumn{3}{|c|}{$1,337.11$} \\
\hline
\end{tabular}

\subsection{Electricity production}

The produced and clean syngas is introduced into a genset consisting of two $100 \%$ syngas engines, to produce electrical energy with a maximum gross power of $10 \mathrm{kWe}$ and also thermal energy from cooling (hot water at $90^{\circ} \mathrm{C}$ ) and from the exhaust gases at approximately $400^{\circ} \mathrm{C}$, also usable. During the operation of both motors, every $30 \mathrm{~min}$ or one hour, the 


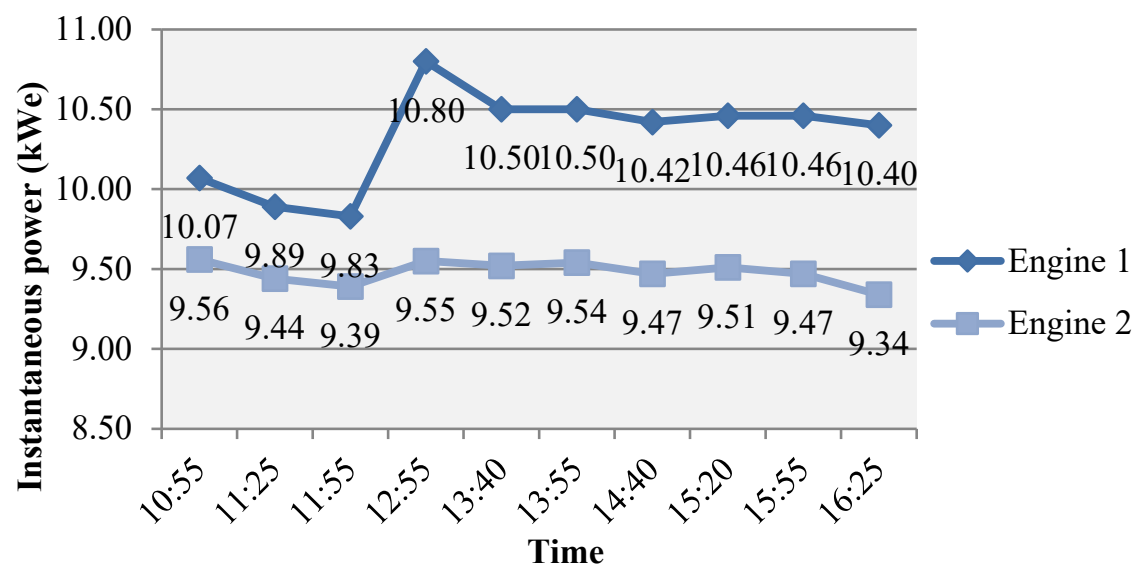

Figure 4: Instantaneous power evolution during the test.

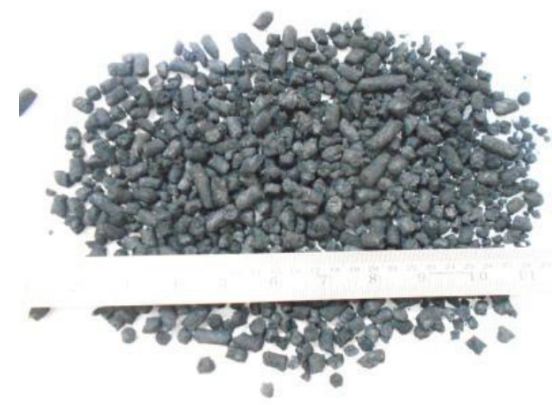

Figure 5: Discharge bio-char photography.

instantaneous power produced is measured, whose measurements can be seen in the graph in Fig. 4. Motor 1 obtains higher instantaneous power values with an average of $10.33 \mathrm{kWe}$, while motor two gets an average of $9.47 \mathrm{kWe}$.

\subsection{Bio-char production}

A solid product called bio-char (Fig. 5) is also obtained from the gasification process, with an average production of $10.77 \mathrm{~kg} / \mathrm{h}$. This represents $14.36 \%$ of PDOP consumption.

Table 4 shows the bio-char physico-chemical characteristic. As can be seen, it has a high moisture content (38.38\%), which is due to the sum of the residue's own moisture, plus that added during discharge in order to decrease its temperature at the gasifier outlet. The characteristics of the bio-char are very good for use as a fuel, since it has a high fixed carbon content $(66.58 \%)$ and a high calorific value $(5,841 \mathrm{kcal} / \mathrm{kg})$, on a dry basis. Furthermore, its volatile content $(6.93 \%)$ is reduced compared to the content present in the raw material (71.77\%). However, it has a high ash content (26.49\%), which can pose a problem for the cleaning and maintenance of combustion equipment. 
Table 4: Physico-chemical analyses of discharge bio-car.

\begin{tabular}{|l|c|}
\hline Parameters & Bio-char \\
\hline Average dry discharge & $10.77 \mathrm{~kg} / \mathrm{h}$ \\
\hline Moisture content, \% wb & 38.38 \\
\hline Ash, \% db & 26.49 \\
\hline Volatile, \% db & 6.93 \\
\hline Fixed carbon, \% db & 66.58 \\
\hline Bulk density, kg/m ${ }^{3}$ & 675 \\
\hline Size, in mm & $0-20$ \\
\hline Ignition test & Burns easily \\
\hline Flow ability test & Flows easily \\
\hline Calorific value, $\mathrm{kcal} / \mathrm{kg} \mathrm{db}$ & 5,841 \\
\hline
\end{tabular}

\section{CONCLUSION}

From the results obtained, it can be deduced that the gasification of the PDOP is a good alternative for the recovery of this kind of waste, since a high gas yield with a high calorific value is obtained, and a carbonaceous residue that can have a very good market. Furthermore, with the PDOP gasification the following advantages are obtained: reduction of energy costs (OPEX) and reduction of $\mathrm{CO}_{2}$ emissions in the olive oil sector; favoring the transition towards a circular economy in this sector. Sector well established in the Mediterranean countries, highlighting above all Spain.

\section{ACKNOWLEDGEMENTS}

The authors thank the University of Jaén and Recursos Estratégicos de biomasa S.L. for financing this work through the "Specific collaboration agreement between Recursos Estratégicos de Biomasa S.L. and the University of Jaén for the development of a doctoral project applied in the co-financing modality" dated 11 Sep. 2018.

\section{REFERENCES}

[1] Agencia de Gestión Agraria y Pesquera de Andalucía, Junta de Andalucía (AGAPA), Evaluación de la producción y usos de los subproductos de las agroindustrias del olivar en Andalucía. Unión Europea: Fondo europeo Agrícola de Desarrollo Rural, 2015. www.juntadeandalucia.es/agriculturaypesca/observatorio/servlet/FrontController?acti on $=$ DownloadS\&table $=11031$ \&element $=1585173 \&$ field=DOCUMENTO. Accessed on: 5 Jun. 2020.

[2] Consejería de Agricultura y Pesca (CAP), Junta de Andalucía, Potencial energético de los subproductos de la industria olivarera en Andalucía. 2010. www.juntadeandalucia.es/export/drupaljda/Potencial\%20energ\%C3\%A9tico.pdf. Accessed on: 5 Jun. 2020.

[3] Roig, A., Cayuela, M.L. \& Sánchez-Monedero, M.A., An overview on olive mill wastes and their valorisation methods. Waste Management, 26, pp. 960-969. DOI: 10.1016/j.wasman.2005.07.024.

[4] Alburquerque, J.A., Gonzálvez, J., García, D. \& Cegarra, J., Agrochemical characterisation of "Alperujo", a solid by-product of the two phase centrifugation method for olive oil extraction. Bioresource Technology, 91, pp. 195-200, 2004.

DOI: $10.1016 / \mathrm{S} 0960-8524(03) 00177-9$. 
[5] Agencia Andaluza de la Energía (AAE), Consejería de Hacienda, Industria y Energía, Junta de Andalucía, La bioenergía en Andalucía, 2020.

www.agenciaandaluzadelaenergia.es/es/biblioteca/la-bioenergia-en-andalucia. Accessed on: 5 Jun. 2020.

[6] Basu, P. (ed.), Introduction. Biomass Gasification and Pyrolysis: Practical Design and Theory, Academic Press, pp. 1-25, 2010.

DOI: 10.1016/B978-0-12-374988-8.00001-5.

[7] Basu, P. (ed.), Gasification theory and modeling of gasifiers. Biomass Gasification Design Handbook, Academic Press: Boston, pp. 117-165, 2010.

DOI: 10.1016/B978-0-12-374988-8.00005-2.

[8] Ciuta, S., Tsiamis, D. \& Castaldi, M.J. (eds), Fundamentals of gasification and pyrolysis. Gasification of Waste Materials, Academic Press, pp. 13-36, 2018. DOI: 10.1016/B978-0-12-812716-2.00002-9.

[9] Situmorang, Y.A., Zhao, Z., Yoshida, A., Abudula, A. \& Guan, G., Small-scale biomass gasification systems for power generation $(<200 \mathrm{~kW}$ class): A review. Renewable and Sustainable Energy Reviews, 117, 109486, 2020.

DOI: 10.1016/j.rser.2019.109486.

[10] Basu, P. (ed.), Design of biomass gasifiers. Biomass Gasification, Pyrolysis and Torrefaction: Practical Design and Theory, Academic Press, pp. 167-228, 2010. DOI: 10.1016/B978-0-12-374988-8.00006-4.

[11] Basu, P. (ed.), Design of biomass gasifiers. Biomass Gasification, Pyrolysis and Torrefaction: Practical Design and Theory, Academic Press, pp. 263-329, 2018. DOI: 10.1016/B978-0-12-812992-0.00008-X.

[12] Guangul, F.M., Sulaiman, S.A. \& Ramli, A., Gasifier selection, design and gasification of oil palm fronds with preheated and unheated gasifying air. Bioresource Technology 126, pp. 224-232, 2012. DOI: 10.1016/j.biortech.2012.09.018. 